\title{
ONE LIFE AND TWO PERSPECTIVES SEPARATED BY THE BORDER The case of Taisto Huuskonen
}

\author{
Tuulikki Kurki
}

\begin{abstract}
This article discusses Finnish writer Taisto Huuskonen who defected to the Soviet Union in 1949. It examines his biographical and testimonial novel, The Child of Finland (Laps' Suomen), which describes Huuskonen's defection and life in the Soviet Union. The focus of the article is to show how Huuskonen constructs 'I', 'we', and 'other' in the novel and how these constructions often produce a complex dilemma of positionality. In the novel, various topographical, symbolical and metaphorical borders are central, and they affect the way that Huuskonen defines his position and agency in relation to ' $\mathrm{I}$ ', 'we', and 'other'. The article argues that the significance of Huuskonen's novel is that it represents the lives and destinies of thousands of Finns. At the same time the novel serves as a medium by which to process the painful experiences he recounts and the miracle of survival. At the time of its publishing in 1979, the novel The Child of Finland was interpreted in the context of the Cold War. Although Huuskonen's purpose was to write a survival story, his story was extensively seen to pronounce the juxtaposition between East and West, which gave it the appearance of a scandal novel vilifying the Soviet Union.
\end{abstract}

Keywords: defection, Finnish communists, life-story writing, testimonial novel, trauma narration, Soviet Union

\section{MOVEMENT ACROSS THE BORDER}

Before the Second World War and especially in the 1920s and 1930s, thousands of workers moved from Finland to Soviet Russia. The most active period of movement was the early 1930 s when 15,000 people moved to the Soviet Union (Vettenniemi 2004: 47; Rislakki \& Lahti-Argutina 1997: 17-19).The reason for their emigration was mostly political. Some of the political emigrants moved to the Soviet Union because they were inspired by the socialist ideology, and the utopia it maintained of the socialist society. Many others moved because of a sheer necessity to avoid imprisonment in Finland. The Communist Party of Finland, which was founded after the war, in 1918, was an underground movement until 1944. During this period, belonging to the Finnish Communist 
Party or participating in its activities provided valid grounds for imprisonment or accusations of treason (Asplund 2011). This made many communists escape across Finland's national border to the Soviet Union. The movement across the national border dwindled in the late 1930s and was almost non-existent by the end of the Second World War. The Cold War period that started after the Second World War and the infamous Iron Curtain that descended on the border, prohibited movement across the border until Perestroika and the collapse of the Soviet Union in 1991.

Taisto Huuskonen defected to the Soviet Union with his fiancée Enni during a time when it seemed most unlikely: 1949. The Second World War had ended only five years earlier and due to the Cold War, the Iron Curtain was already descending on the border between East and West. The military alliance NATO was founded in 1949 and drew the United States and Western Europe closer to each other, while the Soviet Union expanded its communist political system in its satellite countries (Gaddis 2007). In these circumstances, Finland tried to maintain diplomatic but neutral relations with both East and West. Finland and the Soviet Union concluded the Finno-Soviet Treaty in 1948 (The Agreement of Friendship, Cooperation, and Mutual Assistance). The purpose of the treaty was to maintain, develop, and strengthen economic and cultural relations between the countries, and defend peace and security according to the principles declared by the United Nations (Finlex 17/1948). Nevertheless, the relationship between Finland and the Soviet Union was strained. The countries had been enemies in the war only a couple of years earlier. During the immediate post-war years, Finland feared a socialist coup and an occupation by the Soviet Union. Despite the forced neutrality and the treaty between Finland and the Soviet Union, and the fact that Finland did not join NATO, the relationship between Finland and the United States remained friendly (Tarkka 1992: 28-29, 34-35).

Taisto and Enni Huuskonen's defection to the Soviet Union was rather unexpected in the post-war atmosphere of Finland and would indicate that Huuskonen had very strong internal motives for this. According to Huuskonen, his reasons for defecting were his great admiration toward socialism and his desire to start a new and better life in the Soviet Union. His other reasons for defecting can only be speculated upon afterwards, although one motive could be Huuskonen's difficulties with Finnish authorities and his consequent imprisonment had he stayed in Finland. Whatever the reasons for defecting, it had very dramatic and unexpected consequences for Taisto and Enni Huuskonen. Due to their illegal entry into the Soviet Union, Taisto and Enni Huuskonen were first condemned to a prison (forced labour) camp and then later to internal exile within the Soviet Union, and so began a stay of twenty-six years in the Soviet Union. 
In the Soviet Union, Huuskonen became a writer and published three novels: Sprouts of Tomorrow (Huomenen Oraat, 1963), Land is Missing a Farmer (Maa kaipaa isäntää, 1968), and Steel Storm in the Karelian Isthmus (Teräsmyrsky Kannaksella, 1971). What influenced Huuskonen's decision to become a writer was perhaps his life experiences in the Soviet Union rather than an inner desire to write. After settling in Soviet Karelia in the mid-1950s, writing became the only means to earn a living for Huuskonen. His weakened physical health did not allow him to do physically demanding work. When Huuskonen returned to Finland, his reasons for writing changed. In Finland, writing became a tool for processing his traumatic life experiences in the Soviet Union. Narrating and re-narrating became tools for externalising, processing and interpreting his traumatic life-experiences of the past (see Novak 2006: 106-107). Processing of this trauma resulted in his writing his life story and the story of his survival in the Soviet Union. The final product, The Child of Finland (Laps' Suomen), was published in 1979, three years after Taisto and Enni Huuskonen had returned to Finland.

The novel The Child of Finland directs the readers' attention to the crossing of national borders, and particularly how crossing the border makes Huuskonen critically study his own identity and loyalty to different ideologies. The concepts 'I', 'we', and 'other' have a central role in the novel, as Huuskonen uses them to define his identity and position in the world. This article focuses on the question of how Huuskonen constructs 'I', 'we', and 'other' through his writing in The Child of Finland. In this article, 'I' means the narrated 'I' and the narrating voice of the novel, which are both that of the author, Huuskonen. 'We' is a narrated and sometimes rather implicit category, with whom ' $I$ ' forms a sense of solidarity and shares certain values, ideals, and political leaning. The 'other' consists of those who oppose the 'I' and 'we'.

In the novel, 'I', 'we', and 'other' are discursive categories that are redefined continuously in narration. Therefore, the concepts 'I', 'we', and 'other' are not static categories in the novel, but are partially overlapping, and their definition depends upon the side of the border and life experiences that Huuskonen is focusing on. Although the idea of a national border is very central when defining 'I', 'we', and 'other', the symbolic and metaphorical borders seem to be even more significant (see Jaago 2012 in this theme issue).

In this article, Huuskonen's novel is seen as an agent with which the writer can process his traumatic experiences and position himself in the world. The other focus point in this article is to show how Huuskonen's traumatic experiences are integrated into his life-story and the ways they construct his identity. The themes and incidents that Huuskonen has chosen are significant from his point of view and from the point of view of his life-story and identity formation. 
By narrating these themes and events, he makes his life-story meaningful and is able to direct his perspective from the past toward the future, which is typical for such a trauma writing process (see Aarelaid-Tart 2006: 31-33).

The formation of the categories of 'I', 'we', and 'other' can be interpreted in the context of Huuskonen's traumatic life-experiences, in the larger context formed by the Cold War and the political and ideological juxtaposition of East and West. In this article, the constructs of 'I', 'we', and 'other' maintained by Huuskonen and the political atmosphere created by the Cold War are proportioned with each other.

In this article, trauma literature and the testimonial novel are dwelt upon to form a background for the discussion of Huuskonen's work. His novel The Child of Finland is introduced, and in the subsections, the narrative of Huuskonen's life in the Soviet Union is analysed through the concepts of 'I', 'we', and 'other'. Finally the article discusses the public reception of Huuskonen's novel and its significance in a wider context.

\section{THE CHILD OF FINLAND - TRAUMA LITERATURE AND THE TESTIMONIAL NOVEL}

After his return to Finland in 1976, Huuskonen had initially no intention to write about his experiences in the Soviet Union but later changed his mind. One of his motivations to write was to tell the "truth" about life in a socialist society (Huuskonen 1979: 5-6). ${ }^{1}$ Meaningful literary contexts in which to discuss Huuskonen's novel are trauma literature and the testimonial novel, which highlight both the personal and the collective aspect of a traumatic experience.

The novel The Child of Finland is a work of non-fiction written in the firstperson narrative. After publishing it, the novel was defined as a documentary one, based on real life incidents. The back cover of the book introduces it as "a memoir", and "a document" of life in the Soviet Union (Huuskonen 1979). According to Huuskonen, all of the names and dates may not be completely accurate in the novel; however, the "truth" has not been altered in the writing process (ibid.: 5). The question as to whether Huuskonen's novel is truthful or not has not been evaluated in this article. A more important issue than the accuracy of the novel, though, is its focalisation. Taisto Huuskonen and his survival of the prison camp, life in exile as well as in Soviet Karelia are the focus of the narration, which is an adequate requirement for accuracy (for more on focalisation in the testimonial novel, see Vettenniemi 2004: 21-22).

Huuskonen's novel has several features that are typical of trauma literature. Trauma literature is either biographical, fictive literature, or a combination of 
these two, where the author discusses his or her personal trauma or a trauma of the group of people that he or she represents (Aarelaid-Tart 2006). Traumatic stress is "caused by life-threatening or self-threatening events that are accompanied by fear, helplessness, or horror" (Resick 2001: 28, cited in Hout 2011: 331). This extreme stress needs externalisation, processing and signification through narrating and re-narrating. Trauma literature can be composed of fragmentary memories and repetitive descriptions of scenes and images connected with the trauma (Weil 2009: 136). Trauma literature can also be an autobiography, where the experiences of the past are already arranged in a form of a narrative that continues from the past to the present. Huuskonen's novel represents a trauma novel that narrates his life-story from the beginning until the end of his traumatic experience in the Soviet Union.

Despite that the novel focuses on Taisto Huuskonen and the lives of his closest circle of acquaintances, the experiences he describes touched the lives of millions of other Soviet citizens. More specifically, his narrative of defecting from Finland to the Soviet Union echoes the lives of tens of thousands of Finnish defectors and their families. Therefore, the novel can also be characterised as a testimonial novel which is typically written in the first person, and whose function is, as Amy Novak states, "a non-fiction account of the narrator's survival and witness to traumatic events and political oppression that affect not simply their own life but that of their community, culture, or nation" (Novak 2006: 107). Therefore, it can be argued that Huuskonen's novel is not just an isolated individual account of one life tragedy, but one which echoes the lifeexperiences of millions.

\section{THE CHILD OF FINLAND AND MOVING ACROSS THE BORDER}

In the novel The Child of Finland, Huuskonen's life-story includes three important phases. The first is life in Finland, the second - his life in the Soviet Union, and the third - his return to Finland. The novel focuses mainly on the second phase, which describes his life in the Soviet Union and discusses the people Huuskonen met, together with the various incidents he experienced and witnessed. Huuskonen reflects especially on his thoughts and feelings in the prison camp from 1949 to 1951, and in his exile in the Ural region from 1951 to 1954. The remainder of the novel addresses Huuskonen's life in Soviet Karelia from 1954 to 1976.

The first and the third phases (life in Finland and return to Finland) remain somewhat evasive and referential but are nevertheless important to his lifestory. Their significance is revealed as they are understood within the narrative 
whole of the novel. The novel begins and ends with a crossing of the national border. The first crossing was from Finland to the Soviet Union, and the second, from the Soviet Union back to Finland. The drama and intensity of his lifestory is revealed to the reader only after they understand the circumstances and expectations that Huuskonen had when leaving for and returning from the Soviet Union. Crossing the national border is also a sign for the reader: the national border signals the beginning and end of Huuskonen's trauma. All the phases, whether in Finland or in the Soviet Union, and the crossing of borders topographically or symbolically in one direction or another force Huuskonen to change his perception of himself, 'I', 'we', and 'other'.

\section{HUUSKONEN BECOMES A COMIMUNIST IN FINLAND}

At the beginning of the novel The Child of Finland, Huuskonen describes himself as a Finnish Communist although he cannot recall exactly when he became one. Huuskonen was born in Tampere, in Finland, in 1925. His interest in communism, which culminated in the defection to the Soviet Union, grew gradually. His parents belonged to the working class in Finland in the early twentieth century. During that time, working class members were gaining an awareness of the ideas of socialism and communism. Therefore, it is reasonable to assume that the ideas of socialism and communism must not have been strange to Huuskonen as a child.

The reasons that strengthened his interest in communism were the Second World War and the difficulties in returning to ordinary life after the war. Huuskonen was drafted in the last year of the Continuation War in 1944. The war experiences made him think critically about the dominating values and ideals in wartime Finland. Immediately after the Second World War, it was not easy to support communist ideology in Finland due to the prevailing political atmosphere of right wing conservatism. Although the Communist Party became legal in Finland in 1944, communism was not able to change its status of being an anarchist movement. Furthermore, toward the end of the Second World War, the first whiffs of the Cold War were already being felt, which contributed to the ideological drift between the political East and West.

Immediately after the war, Huuskonen worked as a border guard on the south-east border between Finland and the Soviet Union - the very same area through which he would defect to the Soviet Union a couple of years later. Huuskonen also worked in a paper factory in Tampere where he organised an illegal strike and, as a result, lost his job. His transgression in the paper factory was not the only problem he faced. At the end of the 1940s, Huuskonen was 
often involved in fights and brawls and had to answer for his actions in court several times. In the novel The Child of Finland, Huuskonen suspects that many of the fights he was involved in were pre-arranged attempts to make him break the law. Belonging to the Communist Party was not illegal anymore, but violent behaviour and stealing - which he was accused of as well - could have provided reasons for his frequent arrests. Huuskonen, however, thought that the accusations were nothing but acts of persecution. When considering the fear caused by the socialist revolution and the threat of Soviet occupation during the Second World War, it can be argued that the police especially targeted the members of the Communist Party.

Huuskonen's pro-socialist affinities made it impossible to live an ordinary life, and this led to other problems such as alcohol abuse (Huuskonen 1979: 17-19). The inability to organise his personal life made his hatred towards capitalism grow stronger. Finnish society seemed to be the cause of all his difficulties. He saw the Soviet Union as the ideal state and society where he could start a new and better life. In his autobiography (ibid.: 19), Huuskonen describes that, as his 'faith' in socialism became stronger and stronger, he became more and more estranged from Finland. Finally, the Soviet Union shadowed Finland completely in his thoughts.

Huuskonen's description of life in Finland builds very strong categories of 'I', 'we' and 'other'. The narrating 'I', who is Huuskonen himself, represents the 'other' in relation to the authorities and the majority of the people in Finland. During the post-war years, Finland was mostly agrarian. Even though the working class population strengthened its position during the post-war years and many joined the now legal Communist Party, Huuskonen felt hardly any solidarity with the other members of the working class or members of the Communist Party - he felt that he had no real ideological support from them. Therefore, Huuskonen was very unsatisfied with the Finnish Communist Party. However, he felt solidarity with socialists and communists in the Soviet Union and in the late 1940s, before his defection, the socialists in the Soviet Union represented for Huuskonen the category of 'we', which turned out to be unattainable.

\section{THE BORDER CROSSING THAT CHANGES EVERYTHING}

A decisive moment came when, after another fight, the police asked Huuskonen to come for an interview at the local police station. Instead of going to the police station, however, Huuskonen made a radical decision to defect to the Soviet Union. A politically strained atmosphere, problems with the police, and difficul- 
ties in finding work - Huuskonen felt the pressure so strongly that he saw a new life in the Soviet Union as the only rational solution to his problems. Enni doubted his decision, but Taisto was determined.

Taisto and Enni defected to the Soviet Union not once but twice. On October 4, 1949, they crossed the national border between Finland and the Soviet Union in the Parikkala region. The national border between Finland and the Soviet Union is over 1,300 kilometres long, and consists mainly of uninhabited wilderness (see Laurén 2012 in this theme issue). It is controlled by the border guard detachment; however, it seems that crossing the border at the time was fairly easy. Taisto and Enni crawled under the barbed wire and entered the border zone of the Soviet side, but in the darkness and pouring rain they got lost. After a while they crawled under another fence of barbed wire only to find that they were back in Finland. After re-organising their plan, a second crossing of the border succeeded.

A few hundred yards over the border, the couple arrived at the cottage of a Russian border guard. They entered the cottage and explained the cause for their unexpected visit. Within minutes, the cottage was filled with Soviet border guards and soldiers. Long interrogations started immediately and the joy of starting a new life rapidly turned into a nightmare. The couple was first interrogated in the border region of Soviet Karelia, then again in the bordertown of Sortavala, and finally in the capital of Soviet Karelia, Petrozavodsk. In the latter, in the notorious 'Gray House', where many prisoners had their fates sealed, the interrogations lasted for several months. During this time, Taisto and Enni were frequently interrogated about the reasons for their coming to the Soviet Union. Each time the couple insisted that they just wanted to find work and start a better life in the Soviet Union. The interrogators suspected them of being spies and the outcome of the interrogations was that Taisto and Enni Huuskonen were condemned for illegal entry to the Soviet Union. The last glimmer of hope died when Taisto and Enni were separated from each other and sentenced to prison camps in Kiev for two years. After being released in 1951, they were condemned to exile in Kirov Oblast in the Ural region. Therefore they were not able to settle in Soviet Karelia as they had originally wished.

This defection included several border crossings, not only the national border crossing, but several symbolical and metaphorical ones as well. Most importantly, Huuskonen now personally faced the Soviet authorities and the communist system with which he had felt such affinity when in Finland. When Huuskonen crossed the national border, he crossed a border from his harsh everyday reality in Finland to his dream of socialist utopia. However, once he had crossed the topographical border, his first suspicions of the reality of the communist system emerged. Later on, in the notorious Gray House, the utopia 
he had formed was destroyed. This resulted in radical changes in the concepts of 'I', 'we', and 'other'.

Immediately after crossing the national border between Finland and the Soviet Union, Taisto and Enni Huuskonen had to redefine and negotiate their position in relation to East and West, as defined by the Cold War. After crossing the national border, the narrating 'I' became deeply disappointed with the Soviet system and how it treated its citizens. Huuskonen did not recognise the Soviet system and the Soviet authorities as 'we', and they started to represent the 'other' to him. At the same time, Taisto and Enni Huuskonen noticed that they had come to represent the 'other' - the enemy, potential spies, and, finally, criminals for the Soviet authorities.

Huuskonen's feelings of 'otherness' in relation to the Soviet authorities and Soviet citizens continued throughout his time in the prison camp and during exile in Kirov. Huuskonen's life after crossing the Finnish border was determined almost minute by minute by the precise rules and regulations of the new system. Having these rules and regulations been forced upon him increased his feeling of 'otherness' as a foreigner, criminal, prisoner, and exiled person. Huuskonen's dream to become one of the comrades, to belong to a group of 'we' who wanted to build a new socialist union was crushed.

It is self-evident that a prison camp destroying all the signs of individuality, denying the right to be 'I' or rejecting every effort of becoming 'we', undertakes to isolate and alienate a person from any meaningful relationship. In Huuskonen's case, the 'otherness' was created, firstly, by secluding the prisoners from the ordinary society and isolating them in a remote camp. The camp itself was separated from the surrounding landscape by a plank fence and barbed wire, and, furthermore, by a watchtower manned by a guard with a submachine gun placed at each corner of the plank fence. Huuskonen, like the rest of the prisoners, was not allowed to move freely and cross the border of the prison camp, even approaching it too boldly meant an unavoidable death. In Kiev, the topographical border of the prison camp became the most important border that controlled Huuskonen's daily routines and existence. The national border between Finland and the Soviet Union was now only a distant dream, as in his narrative Huuskonen wonders if he was ever going to return to Finland.

Secondly, the prisoners were deprived of their individuality by the prison routines. Huuskonen's physical appearance was changed not only to make him look like a prisoner and similar to everybody else in the prison camp, but also to undress his individuality: his hair was cut off, his personal possessions were taken away, and his clothes were exchanged for prison clothing - for the Soviet system Huuskonen had become simply a faceless prisoner, a number among the 'others'. 
Despite the prisoners being made to look alike by their physical appearance, they were still the 'other' to each other. The prisoners had an internal hierarchy, in which each prisoner had to fight for his own status. Huuskonen was under constant observation and questioned by both the guards and other prisoners. He had to constantly defend himself and prove his position in the camp hierarchy. He managed to keep his status in the hierarchy rather well; however, his relationship with most of the other prisoners remained strained. He felt a sense of solidarity only with a few other prisoners who were Finns and with whom Huuskonen created a sense of unbroken unity, which continued even after being released from the prison camp:

We Finns (except for Tuomas) blended in the best possible way. We spent all our free time together, and talked a lot. Here in faraway Russia, we had formed a small but strong and unbroken group which the other prisoners did not dare to disturb. (Huuskonen 1979: 98.)

In addition to Finns, Enni also belonged to Huuskonen's category of 'we'. He was constantly thinking of her and shared his thoughts with an imaginary Enni. Only occasionally did Huuskonen receive a short message or even a letter through some other prisoners, and this partly imaginary relationship with Enni became one of the few meaningful relationships for Huuskonen during his time in the prison camp.

Taisto and Enni Huuskonen were freed from the prison camp in 1951, after which they were able to live together again. After their release, Taisto and Enni were condemned to exile in the Ural region. In their exile, the routines that enforced their 'otherness' continued, despite the fact that they were considerably free. They had to report to the authorities at certain intervals to make their location known but in the village of exiled people they had to struggle for their living in what was still a rather hostile environment. During this period in the novel, 'we' includes only Taisto and Enni: they can seek support, comfort and solidarity only from each other. However, in the midst of experiencing their 'otherness' together, Taisto and Enni regarded their Finnish nationality as a positive demarcating feature: they were proud of being Finns and tried to seek the company of other Finns. Identifying themselves as Finns became a cornerstone to their identity formation that allowed them to be both 'I' and 'we'. 


\section{BECOMING 'OTHER' TO THE SOVIET SOCIETY AND TO HUUSKONEN HIMSELF}

In 1953, after Stalin's death, Taisto and Enni Huuskonen were able to move to Soviet Karelia as they had originally wished. However, before this was possible, they had to become Soviet citizens, as non-Soviets were not allowed to settle in Soviet Karelia. Therefore, they had to abandon their Finnish citizenship which had been the most important, stable, and the last remaining factor in defining their identity during their imprisonment and exile.

Symbolically, becoming Soviet citizens meant destroying the last connection that had sustained their identity as 'we' and their solidarity with Finns; however, they had to do this before they could settle permanently in the Soviet Union. Finally, in 1954, the couple was granted their Soviet citizenship and was able to move to Soviet Karelia. Acquiring Soviet citizenship was a key to pursue their dream of a better life; nevertheless, Taisto and Enni Huuskonen were not able to celebrate this change. Instead, they found themselves lost because the change of citizenship had profoundly affected their sense of identity. Other Finns, their friends, became disappointed with their decision. Consequently, Taisto and Enni Huuskonen felt that they were growing apart from them.

Despite the fact that Taisto and Enni were now Soviet citizens, their life in Soviet Karelia was defined by the constant feeling of 'otherness'. Huuskonen himself did not adapt well to the village community in Soviet Karelia. For Huuskonen, 'we' primarily included only himself and Enni. In addition, 'we' included, at least partially, their closest relatives in Finland, with whom they could occasionally keep contact through correspondence. However, when some of the relatives visited Taisto and Enni, they noticed that they had become alienated from each other. During this visit, many symbolical borders and barriers emerged. Taisto and Enni and their relatives did not know anything about each other's lives and they found hardly anything to discuss. What effectively hindered their open communication was fear. Huuskonen feared that he or Enni would reveal something negative about the Soviet Union, and this would cause them further problems with the Soviet authorities. Furthermore, to save his dignity, Huuskonen felt that he had to keep up the façade and not reveal the real difficulties they had faced - he was the one who had insisted on defecting to the Soviet Union. This pretence separated Taisto and Enni from each other and from their relatives even further.

In Soviet Karelia, Taisto Huuskonen became a writer, which significantly changed his identity. In his biography, Huuskonen claims that his access to the Soviet Karelian literary world was made possible because the Finnish language literature in Soviet Karelia (which was the literature of the non-Russian 
population) needed more writers, and therefore all the possible writers who could write in the Finnish language were recruited (Huuskonen 1979: 341). ${ }^{2}$ In these circumstances, Huuskonen saw his chance, and he started to write, firstly simply to earn his living. At the beginning of his career, he prepared speeches for the Finnish language radio in Petrozavodsk. Later he worked on the editorial boards of the Finnish newspaper Totuus (Truth) and the Finnish literary journal Punalippu (Red Flag). In the 1960s, he started to write short stories and novels. Becoming a writer changed Huuskonens' perception of himself and resulted in a redefinition of ' $I$ '. As a writer, Huuskonen had to renegotiate his identity and also his belonging to the categories of 'we' and 'other'.

The contradiction that existed between what Huuskonen had experienced and what he had to write was the first situation where Huuskonen had to redefine 'I', 'we' and 'other'. Huuskonen was angered and confused about the Soviet system due to his tragic prison camp and exile experiences. Nevertheless, he had to earn his living by supporting the Soviet system and its ideals and express this in his writing. As a writer, he had to represent the voice of the 'other' against his own views and identity, and this caused a contradiction between 'I' and 'we'. On the other hand, Huuskonen was very intelligent in a sense that he knew that in order to publish and to earn his living he had to follow the conventions of ideologically imbued Socialist Realism, thus Huuskonen needed to silence his critical inner voice ' $I$ ', in order to continue his writing.

The second drift that led to renegotiating ' $\mathrm{T}$ ' and 'we' was the feeling of ambiguity that Huuskonen experienced. Officially in Soviet Karelia, neither the Finnish nationality nor any other was emphasised. Huuskonen represented the 'other' because his inner identity represented the national identity of a Finn. Furthermore, Huuskonen consciously wanted to maintain his 'otherness' so as to maintain his identity. It was his inner 'I' that made him the 'other' in the Soviet society. However, his 'otherness' turned out to be a great advantage for him as a writer. Finnish was his native language, and he mastered it completely. This was a great advantage in Soviet Karelian literary life where Finnish speaking writers were badly needed and only a few were able to publish in Finnish fluently. As such, knowing the Finnish language perhaps aided him in receiving a fairly good reputation and success as a writer.

A third phase which led to Huuskonen's renegotiating 'I' and 'we' was the contradiction between his success as a Soviet writer and his own disillusionment with the ideology of the socialist utopia. In the long run, this further increased his feeling of ambivalence. His contradictive feelings about communism and his literary success had influenced Huuskonen's narration of ' $I$ ' as well. The novel Steel Storm in the Karelian Isthmus made Huuskonen a full-fledged member of the Soviet Karelian literature, and the Soviet literary institution. Prior to 
the novel, Huuskonen had been regarded as an upcoming writer, but after the novel's publication, he became acknowledged. The novel Steel Storm in the Karelian Isthmus speaks about the war between Finland and the Soviet Union. The protagonists in the novel are Finnish soldiers; nevertheless, the novel ends in the victory of the Red Army. The patriotic war theme remained important in the Soviet literature of the late twentieth century; yet, the perspective of the Finnish soldiers that Huuskonen showed in the novel was exceptional in the scope of Soviet literature. Therefore, Huuskonen's novel received publicity as far away as Leningrad and Moscow. In addition, a well-known translator, Vladimir Bogatshov, translated the novel into Russian, and the writer Konstantin Simonov willingly wrote the preface for the Russian edition. The novel was also translated into Estonian, and was finally nominated for the State Prize in Literature in Soviet Karelia. What indicates this success further is that in 1971, Huuskonen was unanimously accepted into the Union of Writers of the USSR.

Despite his elevated status, Huuskonen experienced constantly that he did not completely belong to the Soviet Karelian writers' group. One of the reasons was a feeling of guilt. When Huuskonen became a member of the Union of Writers of the USSR, he received access to all the benefits and privileges that the union provided for its members. This certainly made it easier for him to write and strengthened his professional identity as a writer. Consequently, his living conditions improved. The drawback of his success, however, was that while Huuskonen defined himself as a writer, at the same time he felt guilty about the benefits he received as a professional writer. He noticed that as a member of the Writers' Union he had become one of the privileged citizens who set themselves above the others by receiving and accepting benefits and commodities to which ordinary people did not have access. Furthermore, Huuskonen felt that because of his success he was expected to support communism - an ideal in which he no longer believed. In addition to his guilt, success and honours made Huuskonen feel like a prisoner because he realised that he had lost all his hope of independence as a writer (Huuskonen 1979: 292, 324). It seems that for these reasons, his career started to decline fairly rapidly after he wrote his novel Steel Storm in the Karelian Isthmus, which remained Huuskonen's last significant novel published in Soviet Karelia.

\section{REDEFINING 'I’ AND THE RETURN TO FINLAND}

The process of constantly questioning the ideology of communism, which was the basis of re-defining Huuskonen's identity and the narrating 'I', culminated when the national security agency $\mathrm{KGB}^{3}$ contacted Huuskonen in the 1960s. The 
KGB ordered Huuskonen to become an informant. Huuskonen was expected to provide information about those people who were suspected of spying for Germany. Taisto felt that he had no choice. If he had accepted the task, he would have been in danger of becoming completely 'other' from the perspective of ' $\mathrm{I}$ ' and a representative of everything that he opposed - he would have become 'we' from the perspective of the communist system in Soviet Karelia. If he had rejected the task, he would have maintained his identity of ' $\mathrm{I}$ ' but become the 'other' in the Soviet system. Becoming the 'other' would have risked his own and Enni's freedom, perhaps even their lives. So, Huuskonen managed to balance between the categories of 'we' and 'other'. He met the people that the KGB had ordered him to meet, but did not ask the questions that he was supposed to ask. Finally, the KGB expelled Huuskonen, because he was obviously not very useful to them. Despite that Huuskonen was afraid of the consequences of his dismissal, he was relieved. He was able to step out from the problematic situation where he was in danger of becoming completely 'other' from the perspective of ' $\mathrm{I}$ ' and lose the last remaining values and ideals that maintained his sense of identity.

The constant feeling of 'otherness', moral dilemmas of his material and social privileges, and the contradictions caused by the compulsory requirement to promote socialism publicly against his own views caused Huuskonen severe stress and anxiety. However, at the same time, this stress and anxiety made Huuskonen more determined to find his way back to Finland. The final push that aided him in making this decision was the Conference on Security and Co-operation in Europe, held in Helsinki in 1975, which drew together the political leaders of the Eastern and Western blocks. The conference had a significant impact on increasing co-operation and mitigating the Cold War tensions between East and West. Particularly, the relationship between Finland and the Soviet Union became more open and trusting (Kekkonen 1975, Suomen pääpuheenvuoro August 1, 1975; Seppänen 2007: 401-405). Furthermore, the delegates made a decision according to which all the countries signing the final act of the conference would "deal in a positive and humanitarian spirit with the applications of persons who wish to be reunited with the members of their family" (Conference of Co-operation and Security in Europe 1975: 39). This was good news to Taisto and Enni Huuskonen. The successful outcome of the conference convinced Huuskonen that now was the right time to apply for permission to return home.

Before the late 1970s, returning to Finland from the Soviet Union had been very difficult and many applications had been rejected by the Soviet authorities. However, the outcomes of the Conference on Security and Co-operation in Europe made the application process easier. Huuskonen started with it imme- 
diately after the conference had ended, on August 1, 1975. In early 1976, Taisto and Enni Huuskonen were able to return to Finland permanently. This time crossing the national border was easy because they travelled by train. However, it was once again mentally stressful. For months in advance, Taisto and Enni had been extremely nervous that something would 'come up' and hinder their return to Finland. Their anxiety peaked in the train when the national border crossing came closer and closer. However, nothing alarming transpired and the train crossed the border with Taisto and Enni Huuskonen safely on board. With the extreme mental stress relieved, Huuskonen fell asleep on the bench.

After their return to Finland, Huuskonen felt that he was back home, but he also felt that he had become alienated from both the Soviet and Finnish ideas of communism and socialism. According to Huuskonen, communism was now a religion, an ecstatic state of mind, which blurred thinking and made people to see each other either as friends or enemies (Huuskonen 1979). Huuskonen was severely disappointed with the political views of Finnish communists, because they 'stubbornly' wanted to maintain an idealistic image of the Soviet socio-political system and society that contradicted strongly with Huuskonen's personal experiences. Taisto and Enni Huuskonen had become 'other' for the Finnish communists as well. One of the party members criticised Huuskonen for returning to Finland. For him Huuskonen's returning indicated his disloyalty to the ideology. Huuskonen was embittered by their refusal to acknowledge his traumatic experiences in the Soviet Union. Finally, at the end of his life-story, Huuskonen noticed that he had become 'other' in relation to what he himself had represented thirty years earlier.

\section{TRAUMA NARRATIVE OR A SCANDAL NOVEL?}

When the novel The Child of Finland was published, it received much attention both in Finland and in the Soviet Union. In Finland, the novel sold over 50,000 copies, although it was not much promoted due to its explosive subject (Vettenniemi 2004: 126). The book's success, however, was certainly surprising, considering the time of its publication in 1979. From the late 1960s to the early 1980 s, Finland experienced a period of Finlandisation (Suomettuminen, 1968-1982), a process by which the Soviet Union (the big neighbour) influenced Finland's (the small neighbour) internal politics. The political leadership in Finland had to conform to the demands expressed by Moscow to maintain good relationships with the Soviet Union. Finlandisation meant also the selfcensorship of the Finnish media: negative descriptions of the Soviet Union were simply not allowed. However, historian Erkki Vettenniemi (2004: 126) claims 
that in the late 1970s, the hegemony of the Finnish intelligentsia, who had fully supported the Soviet Union, crumbled. Therefore, according to Vettenniemi, for example those comments that reported the violations of the human rights in the Soviet Union were able to reach the public even though the Finlandisation period was not yet over. However, this change in hegemony does not explain the novel's success completely. One reason for the novel's success and popularity could have been that ordinary Finns were curious about the Soviet Union as they did not have much knowledge of it. Another reason could be that people were so touched by Huuskonen's dramatic survival story. The reason could also be more political: some Finns may have advocated Huuskonen's novel because he wrote so daringly against the socialist utopia.

In the Soviet Union, however, Huuskonen's novel fell on a different ground and The Child of Finland met fierce criticism. High officials in the Union of Writers of the USSR were first to respond. 'From the highest quarter' came an order that the novel must be given "a counter blow". The chairman of the Soviet Karelian Writers' Union, Antti Timonen, was chosen to design and execute it. ${ }^{4}$ Timonen's critical article was published in the newspaper Soviet Karelia (Neuvosto-Karjala, April 11, 1984) and extracts from Timonen's article were published in the newspaper Helsinki Times in Finland (Järjetöntä Neuvostovihaa, Helsingin Sanomat April 18, 1984). The message was clear: Huuskonen had vilified the Soviet Union with no justifiable reason. He had propagated hatred against the Soviet Union and communism. Furthermore, it was claimed that Huuskonen himself had caused all of the problems he faced in the Soviet Union by abusing alcohol and being dishonest. Lastly, Timonen claimed that the novel served right-wing conservative (reactionary) ideology in Finland, asking in his text if the Finnish right-wing intellectuals had no other working methods than spreading dirt and rubbish.

Huuskonen, naturally, reacted strongly to these accusations. He wrote an angry response published in a Finnish tabloid, the Evening News (Parjattu Huuskonen vastaa neuvostokollegan syytöksiin, Iltasanomat April 19, 1984). The debate between Timonen and Huuskonen was rather unprofessional and personally abusive: the writers mainly accused each other of being alcohol abusers and liars. Nevertheless, the debate between Timonen and Huuskonen regarding the novel was not about literature but the different ideas of East and West from the perspective of the Cold War. Timonen and Huuskonen became personifications of the opposition between the political East and West, where no in-between position was possible. In this political turmoil, the significant meaning of the writing of the novel - processing the trauma - was completely overlooked. 
The question of why Antti Timonen delivered his 'counter blow' in 1984, five years after the novel was published, is interesting. One reason could be that in 1984, the Soviet Union became a site of a fierce power struggle. Yuri Andropov was stepping down from power and Konstantin Chernenko was elected president for a short period of time. At this time, the signs of Perestroika were already in the air. Furthermore, as Timonen himself suggests, the ideological Cold War confrontation between East and West had intensified, and the communist regimes felt threatened by the Western ideology (Neuvosto-Karjala April 11, 1984). The power struggle inside the Soviet Union and the ideological rivalry on both sides of the Iron Curtain created a political restlessness which needed to be stabilised. The Soviet political leadership wanted to reject any "anti-Soviet" attitudes to regain stability. Therefore, Huuskonen's novel became seen as one of the many Western works, which clearly damaged the Soviet values and ideological foundations of communism. Therefore, the reception of Huuskonen's novel became more of a political than a literary act.

Another reason for Timonen's counter blow could be that the Soviet officials declared Huuskonen a dissident and ideological traitor. Therefore his novel was regarded as deceitful. Despite that Stalin's era had already been criticised by Soviet intellectuals due to Khrushchev's so called secret speech in 1956 and the Communist Party Congress in 1961, in which Khrushchev revealed Stalin's crimes and launched his anti-Stalinist campaign publically, the Soviet prison camp system was not yet open for discussion (Vettenniemi 2004: 16-17; Taubman 2007: 276-293). An example of this act was Alexander Solzhenitsyn's One Day in the Life of Ivan Denisovich, first published in 1962. At the time of publishing, the novel enjoyed full support of the political leadership. However, soon after publishing, Khrushchev noted that it had been a mistake to publish Solzhenitsyn's work (Yevtushenko 2008: xi-xx). By the late 1970s, there were fewer novels discussing the Soviet Union's recent history in a critical light, and certainly not novels written by outsiders - non-Soviet writers. The Soviet literary world regarded Huuskonen as a foreign writer who had betrayed not only his loyalties towards the communist ideology but also turned his back on the Soviet Union.

\section{THREE DIFFERENT READINGS}

The Child of Finland seems to have three different kinds of readings, which depend on different contexts. The first reading stresses the novel as a personal trauma; the second one emphasises the novel's ideological underpinnings in the 
context of the Cold War, and the third one discusses the novel's significance as a border-crossing narrative and as a narrative of collective trauma.

Undoubtedly, The Child of Finland is a very private account of a personal trauma, which constructs the ideas of political East and West for the reading audience. In the novel, Huuskonen replays an extremely difficult, mentally painful process where he has to reject his old values and ideals, and redefine his identity again and again in order to find his position in the world in relation to East and West, to socialism, to capitalism and to his closest acquaintances. Such a need to rewrite the trauma and narrator's life-story again and again is typical when processing traumatic experiences (Novak 2006).

The novel leaves an impression that Huuskonen consistently defines himself as the 'other'; the underdog, misfit, or the odd one out. This suggests that the 'otherness' that Huuskonen describes can be understood as his constant need to renegotiate his identity and position. In a way, it can be claimed that traumatic experiences formed the basis for Huuskonen's identity (see Weil 2009: 135). The defection to the Soviet Union, the prison camp, and exile, the constant feeling of 'otherness', dissociation and fear were the feelings that defined Huuskonen's identity. This is shown, for example, at the end of the novel, where Huuskonen does not position himself in the juxtaposed categories of 'we' and 'other' as they could easily be determined as East and West in the Cold War rhetorics. Instead, he allows his position to become ambiguous; the state where the sharp divisions between 'I', 'we' and 'other', as well as East and West, become blurred. His constant need to narrate the trauma and renegotiate his identity is exemplified further in his later novels, and especially in his second biographical novel Enni's Story (Ennin Tarina, WSOY, 1984). Enni's Story and The Child of Finland are very similar novels: they both describe the defection to and life in the Soviet Union; however, this time the narrating 'I' is Enni. When read together, The Child of Finland and Enni's Story complement each other and form a biography of a couple.

The literary construction of 'I', 'we' and 'other' was important not only for Huuskonen. The novel can be seen in the context of memoir literature that describes political oppression, prison camp experiences and exile in the Soviet Union. These were the experiences of millions of people in the Soviet Union, whose trials transform The Child of Finland from a personal survival story to a collective trauma novel. Huuskonen's novel can be seen as one of the first models for trauma novels in Finland that was discussed in public.

In processing and signifying traumas that touch the lives of large groups of people, the role of intellectuals is always pronounced. They provide models, and articulate the claims, interests and desires of the wider public (Eyerman 2010: 3). In Finland, the political atmosphere before the late 1970s and 1980s 
did not allow for a public discussion of the fates and experiences of Finnish defectors to the Soviet Union, although some cultural models of processing these traumas about prison camps and exile in the Soviet Union had already been published in the 1920s. Erkki Vettenniemi (2004) has listed 38 novels published in Finland on this subject until 2003. For example, such novels as Kirsti Huurre's Under the Sickle and the Hammer (Sirpin ja Moukarin Alla, WSOY, 1942), and Urpo Parvilahti's Berija's Gardens (Berijan Tarhat, Otava, 1957) were published already in the 1940s and 1950s. However, these novels were regarded as politically dangerous in Finland and therefore were removed from bookstores during the times of increased tension between Finland and the Soviet Union. Criticising the Soviet Union was politically dangerous and risked the relationship between Finland and the Soviet Union (Ekholm 1996). These literary works due to their explosive subject matter were censored and any discussion of them was suffocated. However, in the late 1970s, the political atmosphere in Finland became more permissive towards such criticism of the Soviet Union and, consequently, the various testimonials of defected Finns and Ingrian Finns who most severely experienced the Soviet oppression were published.

When The Child of Finland was published, the high level politicians neither in Finland nor in the Soviet Union accepted it. Therefore, the novel's second reading reflects those larger political discourses on East and West of the time: ideological confrontation between East and West in all spheres of life, vilifying the ideological other and the support of one's 'own' ideology on both sides of the national border between Finland and the Soviet Union. In the context of the Cold War and the rhetorics maintained by it, The Child of Finland appeared merely as a scandal novel, whose only purpose was to vilify the Soviet Union. As such, the personal narrative of surviving the trauma was made less significant by this interpretation.

The third meaningful context of reading Huuskonen's The Child of Finland has become relevant during the past decade, where the role of topographical borders have changed globally. Due to global changes, literature discussing the traumatic experiences of émigrés and refugees, as well as life in national and cultural borderlands has increased dramatically. In this context, Huuskonen's novel can be read as fiction discussing traumatic experiences at various topographical and symbolic borders (see Langer 2002; Sadowski-Smith 2008). Therefore, Huuskonen's novel can hardly be of any shock value to its readers today. Instead, the novel's value as a survival story and as a means of processing a cultural trauma can shine through to the contemporary readers. 


\section{ACKNOWLEDGEMENT}

This research was supported by the project Writing Cultures and Traditions at Borders (SA131578).

\section{NOTES}

1 One factor that could have hindered his enthusiasm for writing could be the prohibition from telling about his experiences in the prison camp. When the prisoners were released from the prison camp, they had to sign an agreement that they would not tell about their experiences in public. Huuskonen signed the agreement without knowing its contents. The agreement was written in the Russian language which Huuskonen did not then understand and no-one explained the content to him. For these reasons, Huuskonen considered that it did not apply to him (Huuskonen 1979: 131). In addition, the publishing was delayed because Huuskonen did not dare publish the novel until he had regained his Finnish citizenship in 1979.

2 Finnish-language literature was created for the non-Russian population of Soviet Karelia in the 1920s. It was written by Karelians, Finns, and Ingrian-Finns. During the Soviet era, its existence was supported by the Soviet language and nationality policies.

$3 \mathrm{KGB}$, the national security agency of the Soviet Union (Komitet gosudarstvennoi bezopasnosti SSSR). The KGB governed the organisations of security, intelligence and the secret police in the Soviet Union from 1954-1991 (Butler 2008: 147, 186). The KGB had a broad network of special departments in all major government institutions, enterprises and factories, and it recruited informers (Organisation of the Committee for State Security, http://www.fas.org/irp/world/russia/kgb/su0514.htm).

4 Timonen, Writings 1975-1990, Source 1075, list 2, item 112.

\section{ARCHIVAL SOURCES}

Antti Timonen. Writings 1975-1990. Source 1075, list 2, item 112. The National Archive of the Republic of Karelia.

\section{REFERENCES}

Aarelaid-Tart, Aili 2006. Cultural Trauma and Life Stories. Helsinki: Kikimora Publications.

Asplund, Allan 2011. Kokemuksia suomalaisilta keskitysleireiltä. [Experiences from Finnish Concentration Camps.] Helsinki: Like. 
Butler, Rupert 2008. Neuvosto-Venäjän mustat vuodet. Salainen poliisi tsaarinajoista nykypäivään. [The Black Years of Soviet-Russia. The Secrect Police from the Tsarist Era Until Today.] Helsinki: Minerva.

Conference on Co-operation and Security in Europe 1975. Final Act. http://www.osce. org/mc/39501, last accessed on November 20, 2012.

Ekholm, Kai (ed.) 1996. Kielletyt kirjat. [Forbidden Books.] Helsinki: Eduskunnan kirjasto.

Eyerman, Ron 2010. Cultural Trauma: Slavery and the Formation of African American Identity. Cambridge: Cambridge University Press, doi:10.1525/california/9780520235946.003.0003.

Finlex 17/1948. Sopimus ystävyydestä, yhteistoiminnasta ja keskinäisestä avunannosta Suomen Tasavallan ja Sosialistisen Neuvostotasavaltain Liiton välillä. Finlex valtion säädöstietopankki. [Agreement of Friendship, Co-operation, and Mutual Assistance between the Republic of Finland and the Union of Soviet Socialist Republics.] http://www.finlex.fi/fi/sopimukset/sopsteksti/1948/19480017/19480017_2, last accessed on December 15, 2011.

Gaddis, John Lewis 2007. The Cold War. A New History. New York: Penguine Books.

Hout, Syrine 2011. Cultural hybridity, trauma, and memory in diasporic anglophones Lebanese fiction. Journal of Postcolonial Writing, Vol. 47, No. 3, pp. 330-342, doi:10.1080/17449855.2011.569376.

Huuskonen, Taisto 1979. Laps' Suomen. [The Child of Finland.] Helsinki: WSOY.

Huuskonen, Taisto 1984. Ennin tarina. [Enni's Story.] Helsinki: WSOY.

Järjetöntä Neuvostovihaa. [Irrational Hatred Towards the Soviet Union.] Helsingin Sanomat [newspaper], April 18, 1984.

Kekkonen, Urho 1975. ETYK:n III vaihe. Suomen pääpuheenvuoro. [Third Phase of ETYK. The Main Speech of Finland.] August 1, 1975. Doria, National Library of Finland. Urho Kekkonen's published works. http://www.doria.fi/ handle/10024/8380?show=full, last accessed on January 11, 2012.

Langer, Jennifer 2002. Crossing the Border. Voices of Refugee and Exiled Women. Nottingham: Five Leaves Publications.

Novak, Amy 2006. "A Marred Testament”: Cultural Trauma and Narrative in Danticat's The Farming of Bones. Arizona Quarterly, Vol. 62, No. 4, pp. 93-120, doi:10.1353/ arq.2006.0027.

Organization of the Committee for State Security. Federation of American Scientists. http://www.fas.org/irp/world/russia/kgb/su0514.htm, last accessed on September 4, 2012.

Parjattu Huuskonen vastaa neuvostokollegan syytöksiin: Timosella on käsky kirjoittaa omiaan. [Blamed Huuskonen Answers the Accusations Presented by the Soviet Colleague: Timonen Was Ordered to Write Untrue Claims.] Iltasanomat [newspaper], April 19, 1984.

Resick, Patricia A. 2001. Stress and Trauma. London: Psychology Press.

Rislakki, Jukka \& Lahti-Argutina, Eila 1997. Meillä ei kotia täällä. Suomalaisten loikkarien joukkotuho Uralilla 1938. [We Have No Home Here: Mass Destruction of Finnish Defectors in Urals in 1938.] Helsinki: Otava. 
Sadowski-Smith, Claudia 2008. Border Fictions. Globalization, Empire, and Writing at the Boundaries of the United States. Charlottesville and London: University of Virginia Press.

Seppänen, Esa 2007. Itäsuhteiden kolmiodraama. Kekkonen-Brezhnev-Kosygin 19601980. [Triangle Drama of Relationships with East. Kekkonen-Brezhnev-Kosygin 1960-1980.] Helsinki: Ajatus kirjat.

Tarkka, Jukka 1992. Suomen kylmä sota. Miten viattomuudesta tuli voima. [Finland's Cold War: How Innocence Became Power.] Helsinki: Otava.

Taubman, William 2007. Khrushchov-mies ja hänen aikakautensa. [Khrushchev - Man And His Era.] Helsinki: Art House.

Timonen, Antti 1984. Riehaantunut neuvostovihan lietsoja. [Bewildered Agitator of Hatred Towards the Soviet Union.] Neuvosto-Karjala [newspaper], April 11, 1984.

Vettenniemi, Erkki 2004. Punaisen terrorin todistajat. Neuvostoliitto suomalaisten leirivankien muistelmissa. [Wittnesses of the Red Terror. Soviet Union as It Is Remembered by Finnish Camp Prisoners.] Helsinki: SKS.

van der Weil, Reina 2009. Trauma as Site of Identity: The Case of Jeanette Winterson and Frida Kahlo. Women: A Cultural Review, Vol. 20, No. 2, pp. 135-156, doi: 10.1080/09574040903000795.

Yevtushenko, Yevgeny 2008. Introduction. In: Alexander Solzhenitsyn. One Day in the Life of Ivan Denisovich. New York: Signet Classics. 